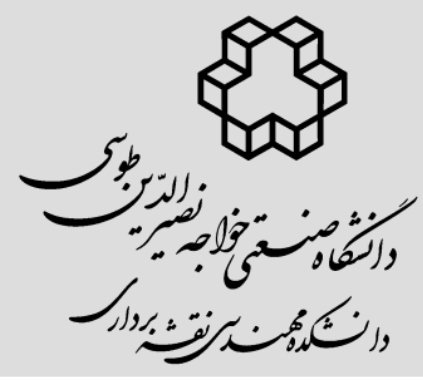

itris

سال يكم، شماره اول، ياييز بوسر

Vol.1, No.2, Autumn 2013

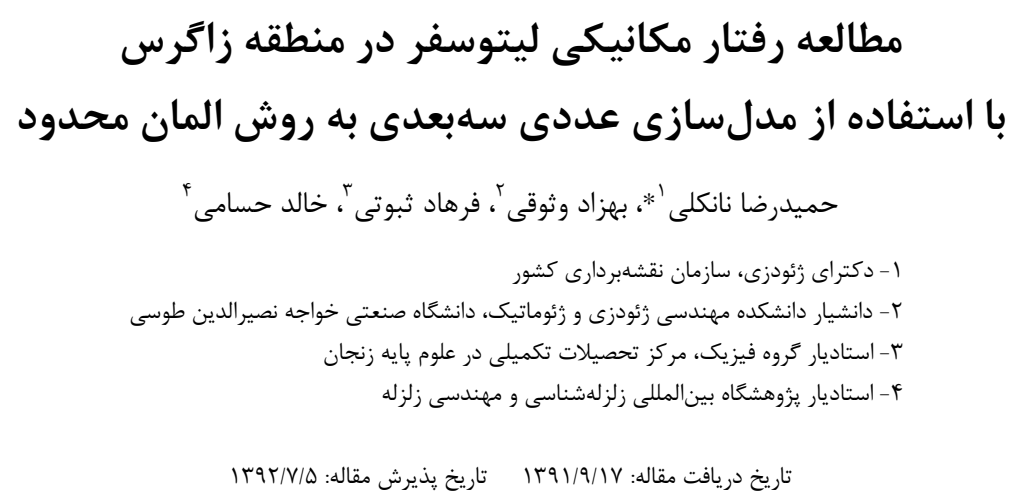

جكيده

مطالعه رفتار و مرز تغيير شكل ليتوسفر به عنوان لايه مكانيكى قوىاى كه شامل يوسته و مانتل بالايى استه، از جمله مباحث روز علوم

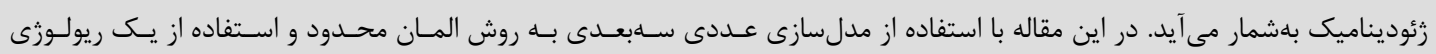
ويسكوز وابسته به دما (خزشى) در دو حالت Dry Wet رفتار مكانيكى ليتوسفر در زاكرس بـا استفاده از دو رئوترم Hot و Cold مـورد بررسى قرار مى كيرد. ضخامت يوسته بالاو وايين و همجنين قسمت مانتل بالايى براساس نكاشتهـاى زلزلـهناسى در منـاطق مختلف زاكرس در نظر كرفته شده است. كسل ها بهصورت المانهاى ويزّه در مدل جاسازى شدند و از قانون كولمب پيروى مى كنند. نتايج نشان

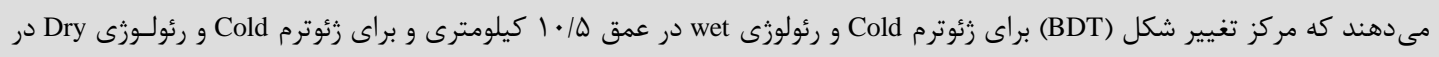

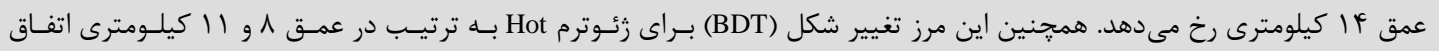
مى افتد. اين نتايج با عمق زلزلههايى كه در منطقه زاكرس رخ مى دهد، تطابق خوبى دارد و حـاكى از آن است كـه اسـتحكام ليتوسـفر در قسمت يوسته متمركز شده است. كليدوازهها: رئولورى، المان محدود، ليتوسفر، زئوترم، زاكرس.

Email: nankali@ncc.org.ir 


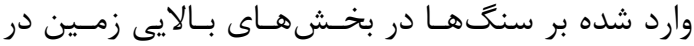

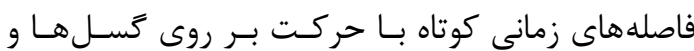

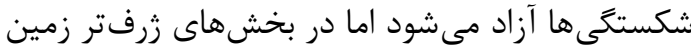

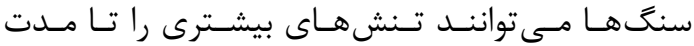

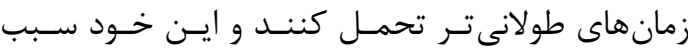

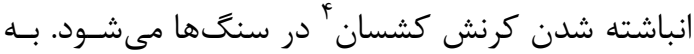

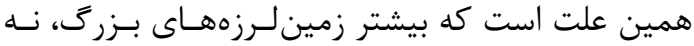
نزديك به سطح زمين بلكه در زرفا روى مى دهند. در سالهاى اخير مدل سازى عددى به عنوان ابزارى

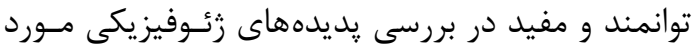

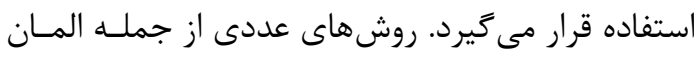
محدود و تفاضل محدود به صورت كستردهاى در مسائل

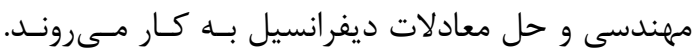

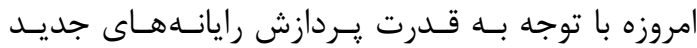
مسئله طولانى بودن زمان محاسبات نيز تا حد زيادى از

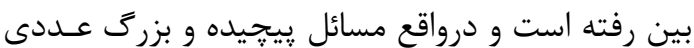
با كمترين زمان ممكن حل مىشوند. اين موضوع باعـث

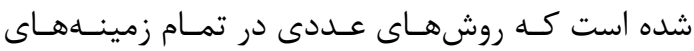
يديدهاى زئوفيزيك اسـتفاده شــند، كـهـ از آن جملـهـ

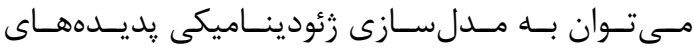
تكتونيكى ـ مثل فـرورانش، كـوهزايى و تعيـين ميـدان كرنش - اشاره كرد.

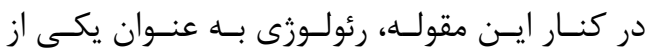

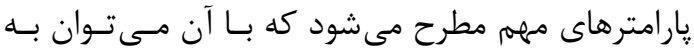

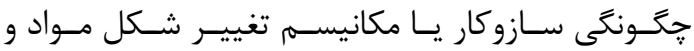

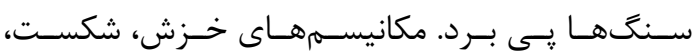

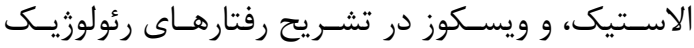
زمين به كار برده مىشوند. مههمترين هدف اين تحقيـق ارائه مدل عددى سهبعدى جديدى براى منطقه زاكرس برد

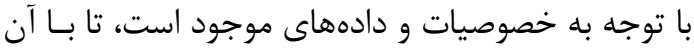
بتوان به جنين يرسشهايى پِاسخ داد:

1. seismic sources

2. Stress

3. elastic rebound

4. elastic strain

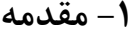

جشمهاى لرزمزا' عارضههايى هستند كه زمين لـرزهــا از آنها منشأ مى كيرند و موجهاى صادر شـده از آنهـا در تمام جهات در درون زمين يخش مسى شـوند. گَسـلهـا

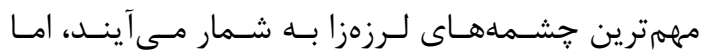

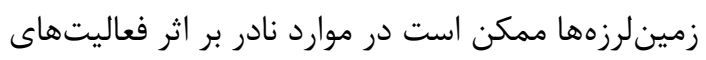
آتشفشانى، ريزش سقف غارها و انفجارهاى هستهاى نيز

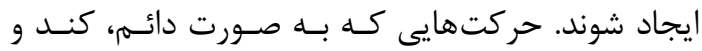
نامحسوس در بخشهاى بيرونى زمين روى مسى دهنـد،

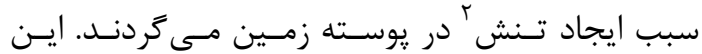
تنشها به تدريج انباشته مى شوند و هنكامى كـهـ مقـــار

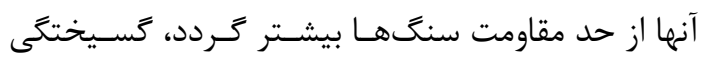
روى مى دهد؛ و به اين ترتيب بخش بزركى از تنشهايى

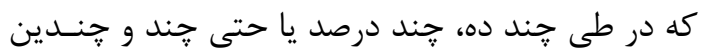

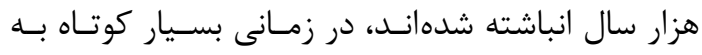

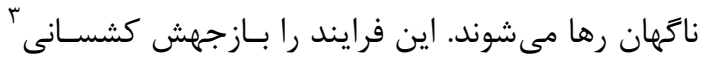

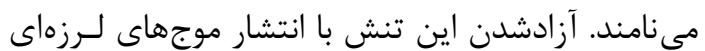
(زمينلرزه) همراه است. بيشتر زمينـلـرزهــاى دنيـا در

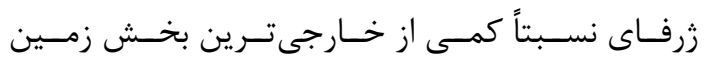

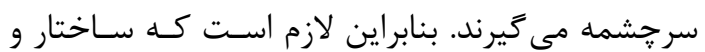
رفتار مكانيكى بخش خارجى زمسين يـا ليتوسـفر مـورد

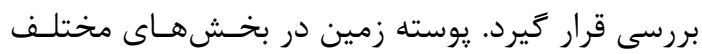

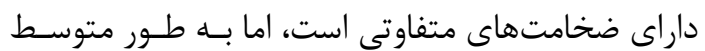
مى توان ضخامتى در حدود هـ كيلومتر را براى يوســـه در بخش هاى قارهاى (خشكى ها) در نظر كرفت. در زئر

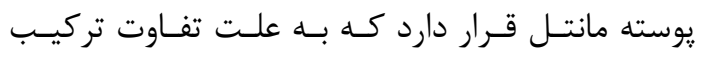
سنگشناسى، رفتار مكانيكىاى متفاوت از يوسته دارد. در خود يوسته نيز مواد تفاوتهايى با هم دارنـد، امـا دو عامل ديخر بر رفتار مكانيكى سنگ هاى يوسته بيشترين تأثير را مى كذارند. فشار و دما با عبور از سطح به زرفاي مائي

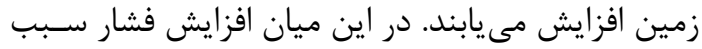

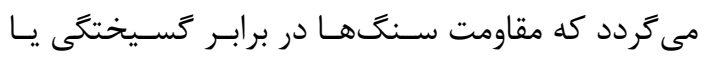

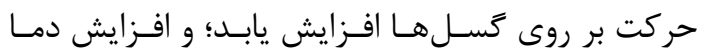

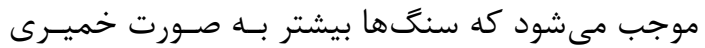

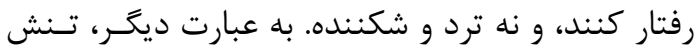


شهرهاى يرجمعيت اين بخش از كشور مانند اهـواز، شـيراز،

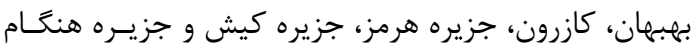

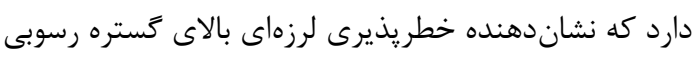

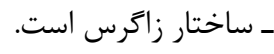

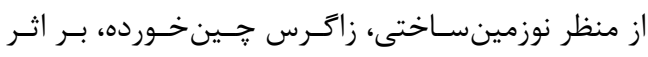

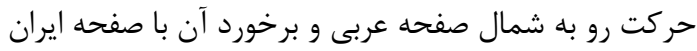

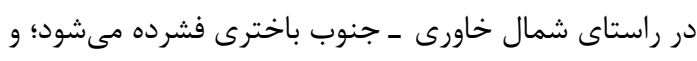

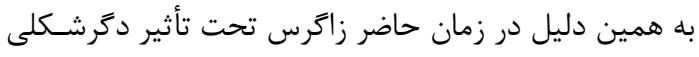

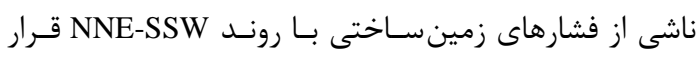

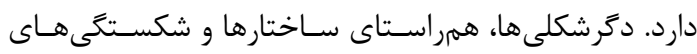

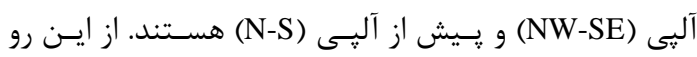

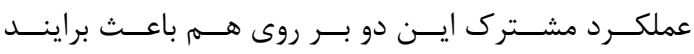

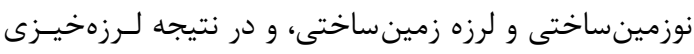

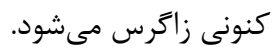

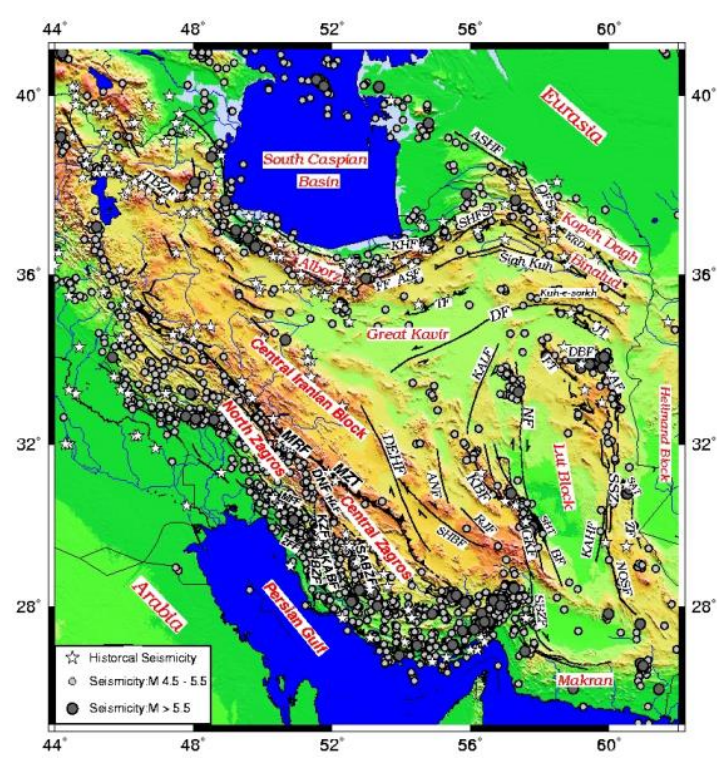

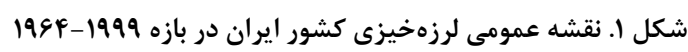

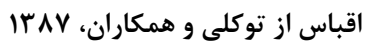

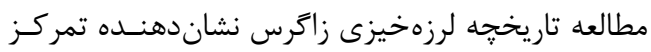

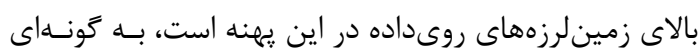

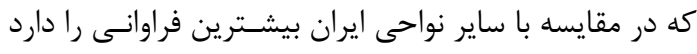

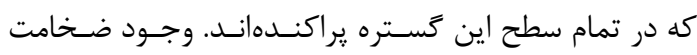

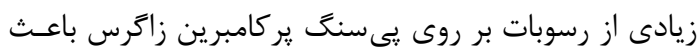

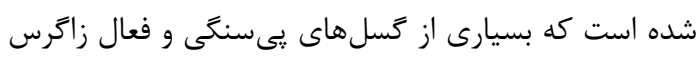
در زير اين يوشش رسوبى مخفى بمانند.

$$
\begin{aligned}
& \text { Y. رفتار مكانيكى بلندمدت ليتوسفر جَّونه است؟ }
\end{aligned}
$$

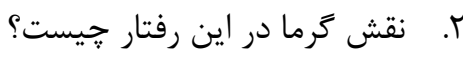

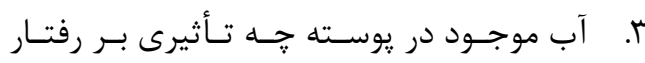

$$
\begin{aligned}
& \text { مكانيكى بلندمدت ليتوسفر دارد؟ }
\end{aligned}
$$

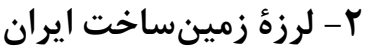

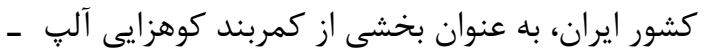

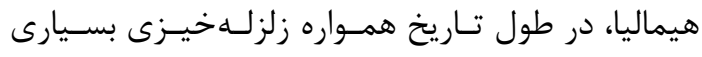

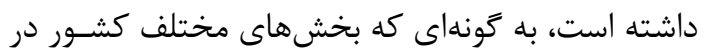

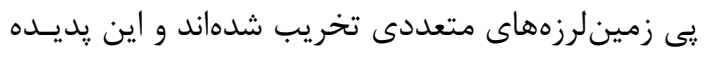
طبيعى مهمترين بلاى طبيعى كشور محسوب مى زئسود.

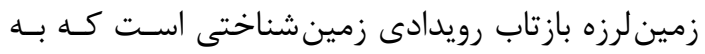

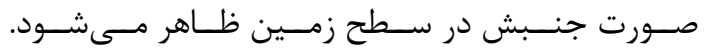

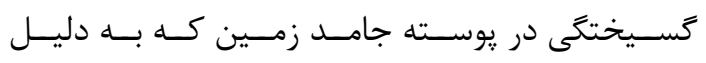

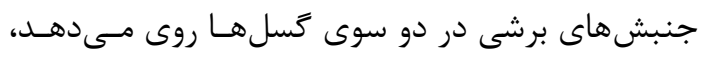

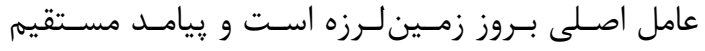

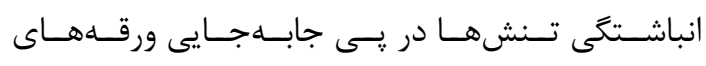

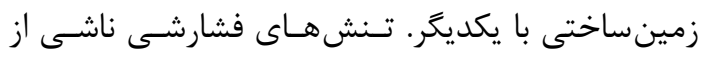

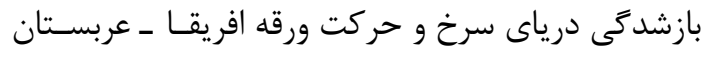

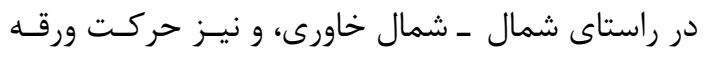

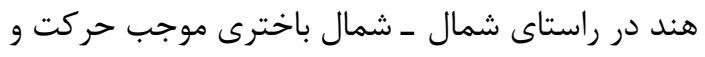

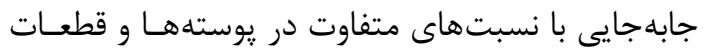

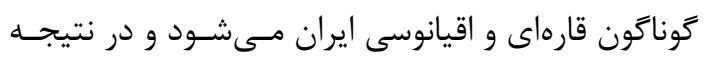

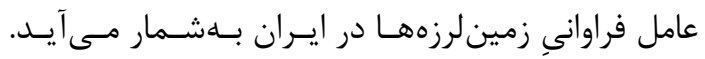

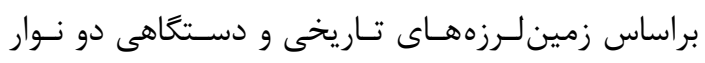

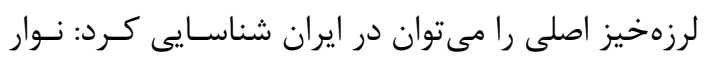

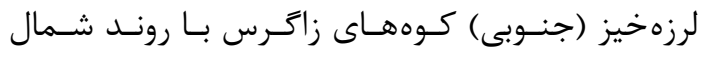

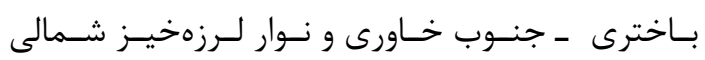

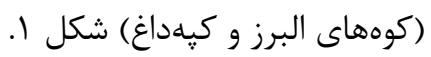

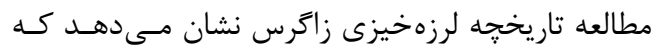

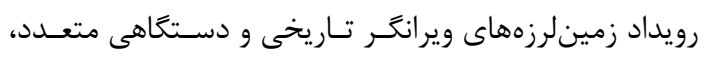
مناطق بسيارى رادر اين كستره از كشور ويران كرده است

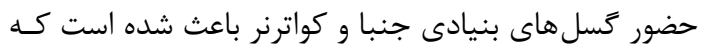

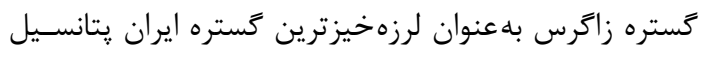

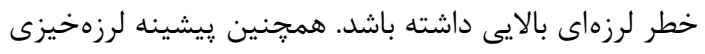

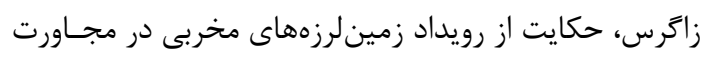




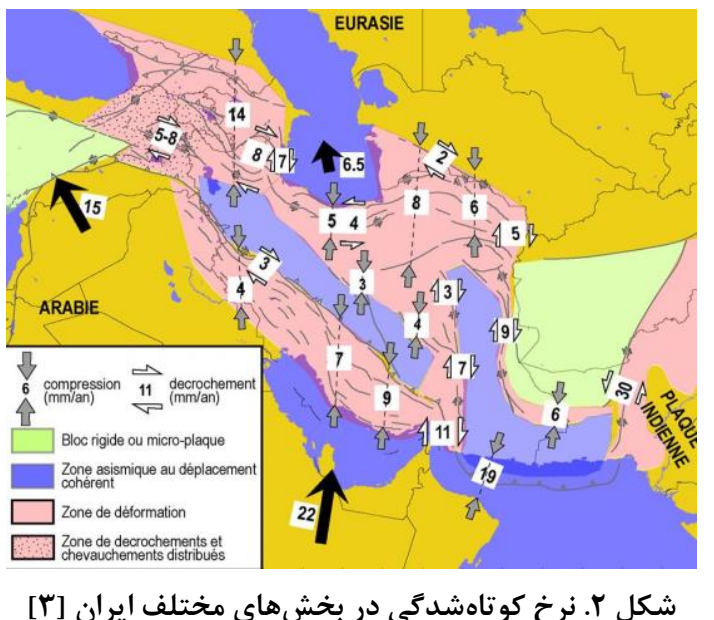

شكل r. نرخ كوتاهشدكى در بخشهاى مختلف ايران [r]

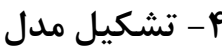

همان طور كه اشاره شد، شبيهسازى عـددى در ايسن تحقيـق مكدل

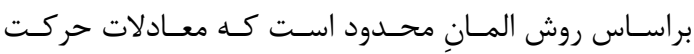

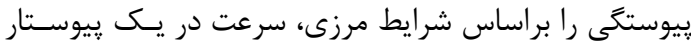

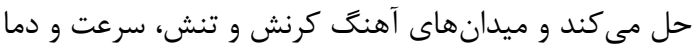

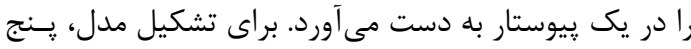
نكته ذيل در نظر گرفته شده است:

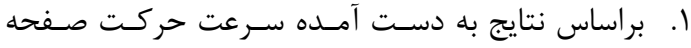

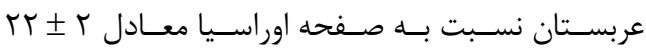

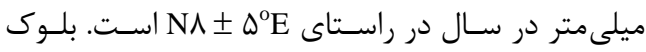

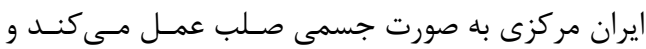

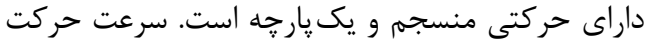

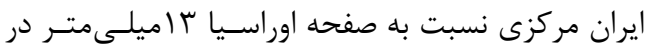
سال است [ب]. Y. دو گسل اصلى عهد حاضـر (MRF) و كـازرون در مــدل

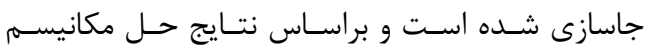

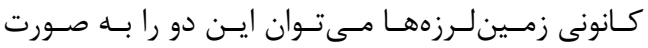

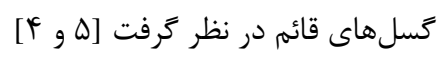

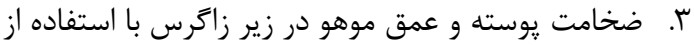

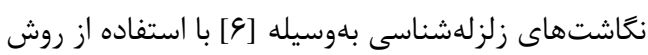

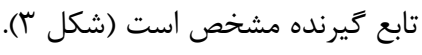

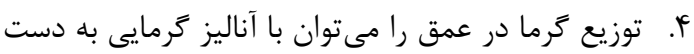
آورد. - مانع ه. بــا اسـتفاده از ميــدانهــاى سـرعت حاصـل از GPS در

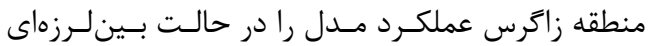

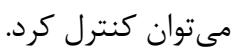

\section{ץ- نرخ هم كرايى در مناطق مختلف ايران}

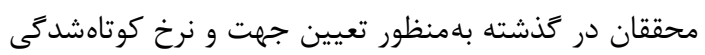

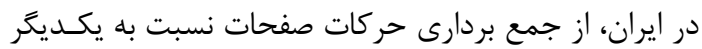

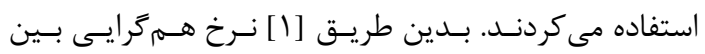

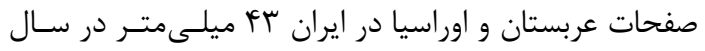

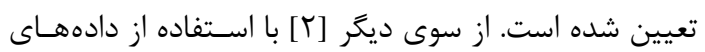

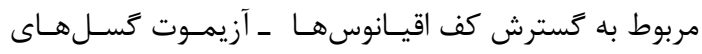

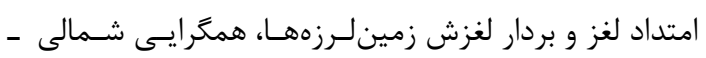

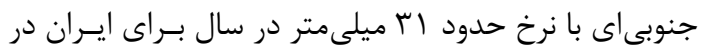

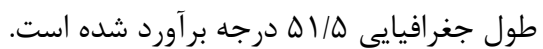

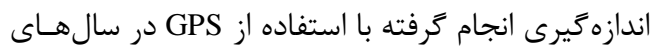

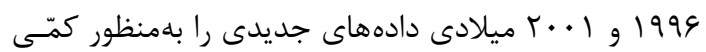

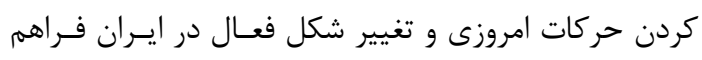

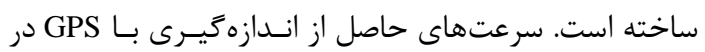

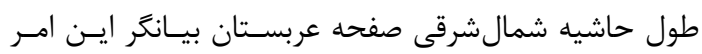
است كه صفحه عربستان نسبت به اوراسيا با سرعتى كمتر از

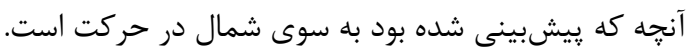

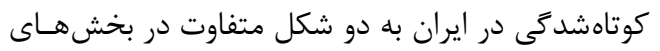

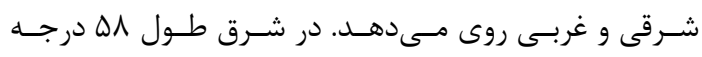

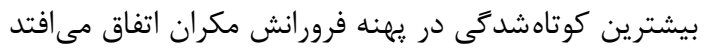

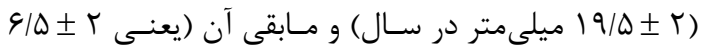

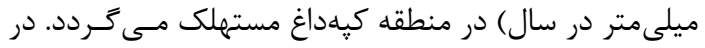

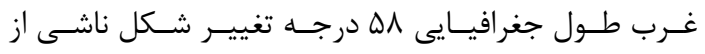

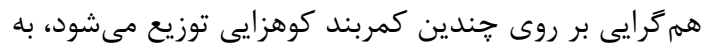

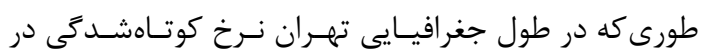

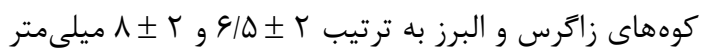
در سال است.

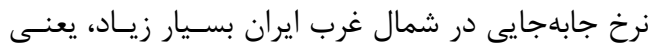

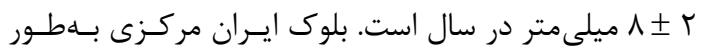

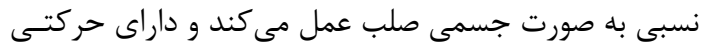

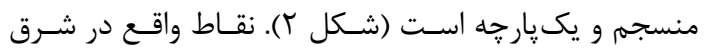

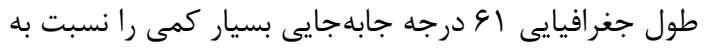

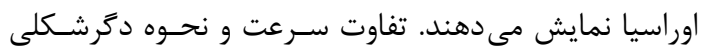
مشاهده شده در شرق و غرب ايران در قالب حركات امتـداد درداد

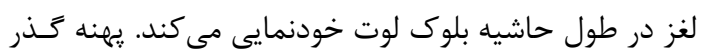

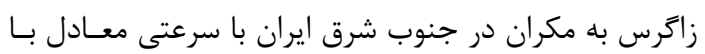

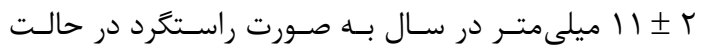

حركت است [ب]. 
ضريب اصطكاك ب استرس برشى بـر روى سطحح

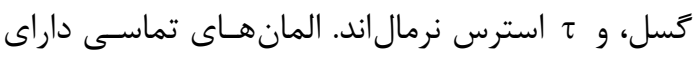

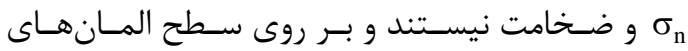
صفحه گسلى قرار مى گيرند.

ه- - هندسه مدل و شبكهبندى مرزهاى جغرافيايى مدل در شكل أ نمـايش داده شـده است. مرزهاى مدل به موازات كمربند زاتحرس و عمـود مدرد

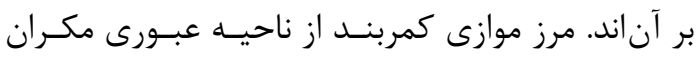

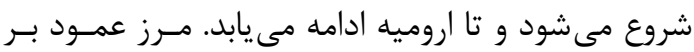

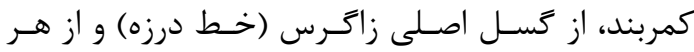

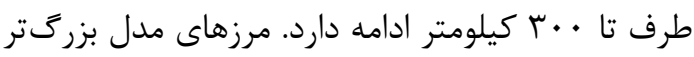

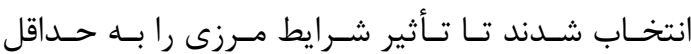

$$
\text { برساند. }
$$

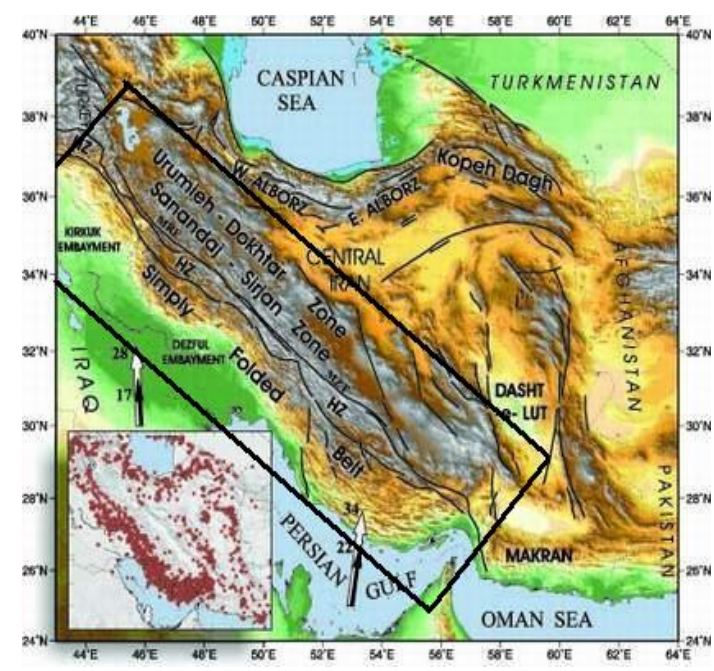

شكل F. نقشه تكتونيكى ايران خطوط ير رنتَ مشكى

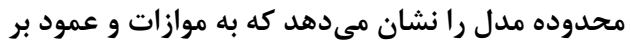

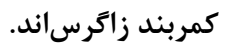

بعـد از تعيـين مــدل هندسـى بايسـتى المـانهــاى

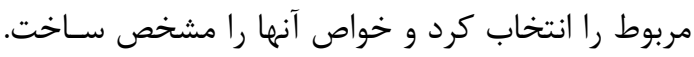

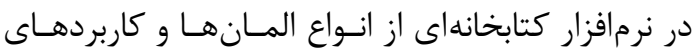
مختلف Ansys وجود دارد. با توجه بـهـ ســلايـهـ بـودن مدل و سهبعدى بودن آن المانهاى سـهبعـدى انتخــاب
مدل المان محدود زاكرس از سه لايه تشكيل شـده

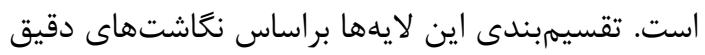

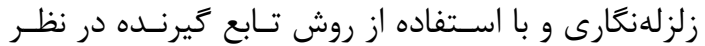
كرفته شده است. برطبق اين مطالعات، يوسته بـالايى از

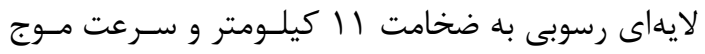

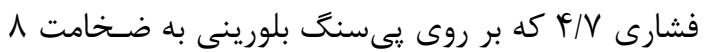

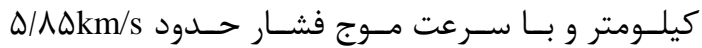
تشكيل شده اسـت و ضـخامت يوسـته زيــرين در ايـن

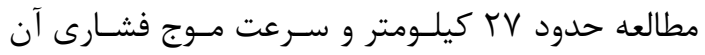

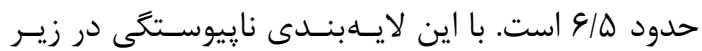
زاگرس در عمق ع كيلومتر قرار دارد.

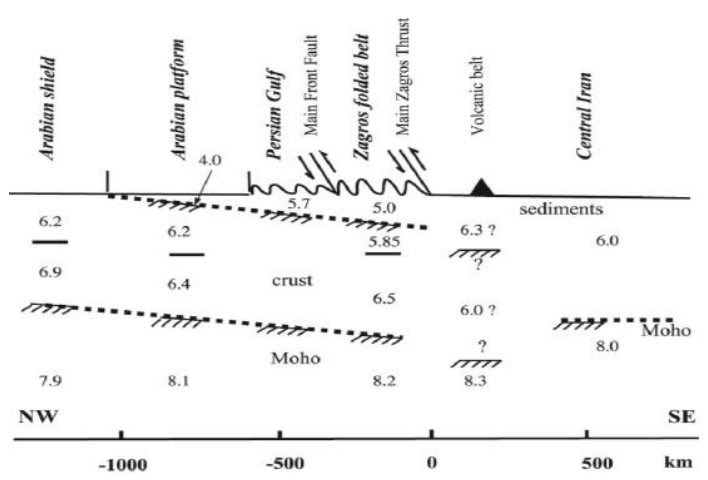

شكل rّ. مقطع عرضى از ليتوسفر در زاترس [8]

با توجه به نتايج مذكور، در اين مدلسـازى يوسـته

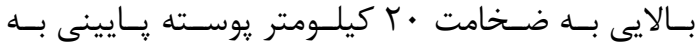

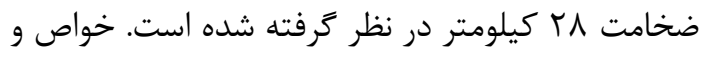

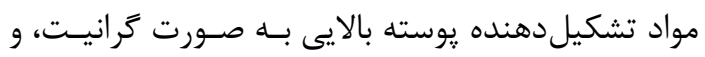

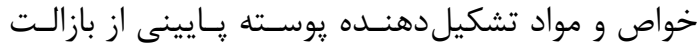

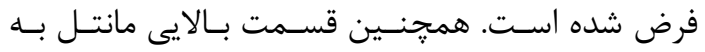

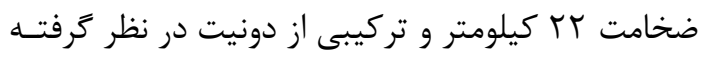
شده است. دو كسل كازرون و عهد حاضر بلوسـيله المـانهـاى

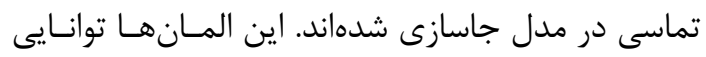
لغزش تغيير شكل، نفوذ و انتقال حـرارت در يكـديخر را إنائ

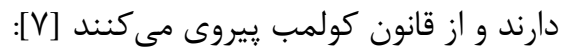
$\mathrm{CF}=\tau+\mu\left(\sigma_{\mathrm{n}}\right)$
رابطه (1) 
خ - خواص مواد

خواص مواد به كار برده شده در اين مدل سازى براساس

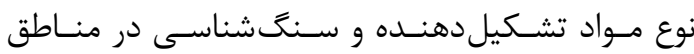

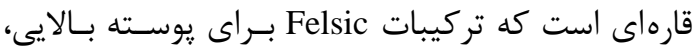

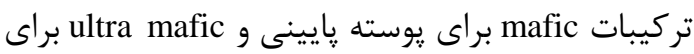

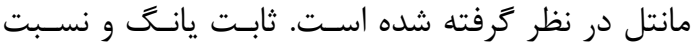

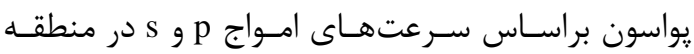
زاكرس محاسبه شده است [9]. دانسـيته بـراى يوسـته

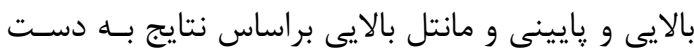

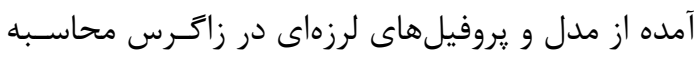

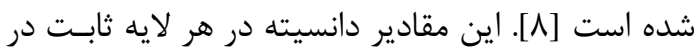

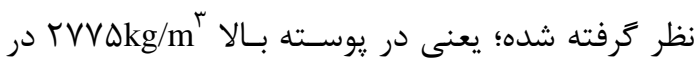

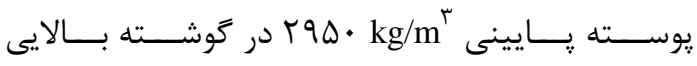

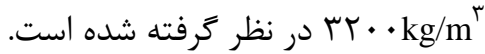

^- شار حرارتى و توزيع ترما در مدل مكانيسم اصلى انتقال گرما (رسانا) در ليتوسفر بهوسيله

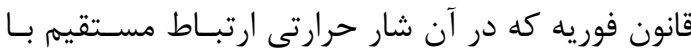
كراديان درجه حرارت دارد، بيان مى كردد: $\nabla(\nabla . T)=-A / k, q=-k \frac{\partial T}{\partial z} \quad$ رابطه (T)

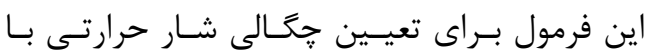

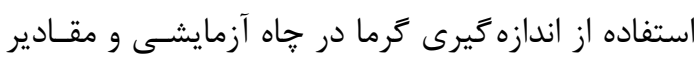
آزمايشكاهى ضريب رسانش به كار برده مىشود.

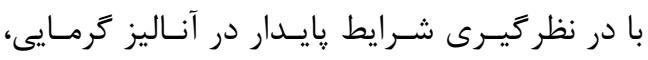
يعنى: 0 آ آن مى توان به محاسبه زئوترم پايدار در ليتوسفر رسيد.

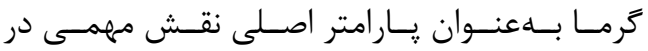

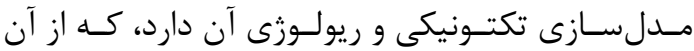

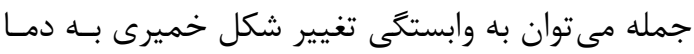
در فرم غيرخطى اشاره كرد.

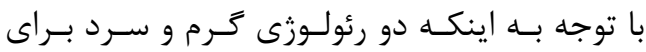

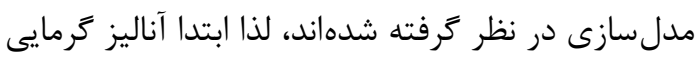

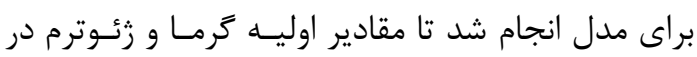

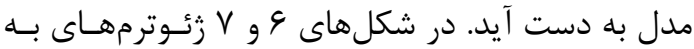

كرديد كه خواص مدل را در دو حالت سازهاى ـ حرارتى

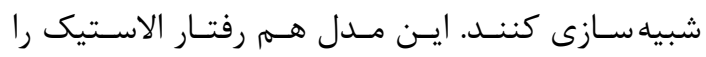
يشتيبانى مى كند و هم رفتار خزشى را.

\section{9- 9- وبكدبندى مدل}

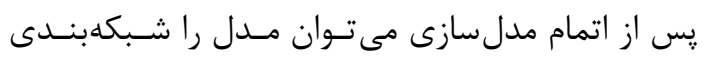

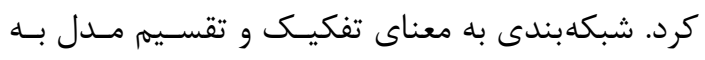
بخش هاى كوجكـتر (المان) است. در ايـن مرحلـه نيـز

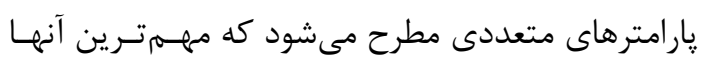
انتخاب ابعاد مناسب براى المانها در شبكدبندى اسـتـ

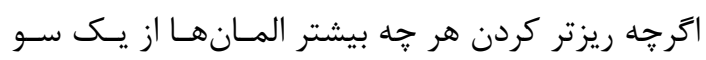

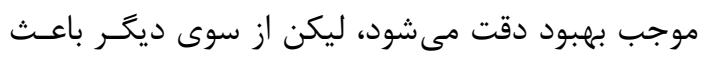

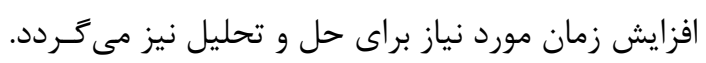

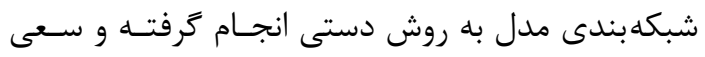

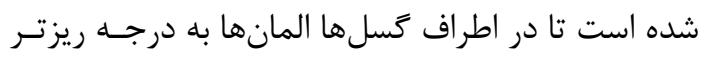

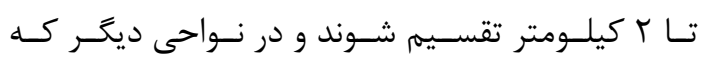

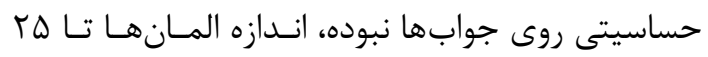

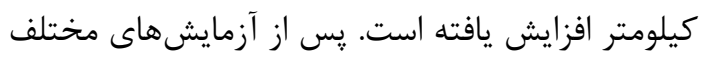

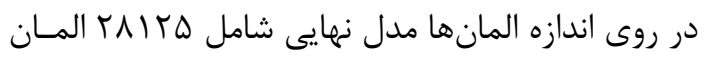

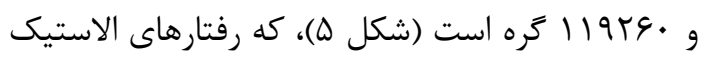
و خزشى (رئولوزى مدل) را شبيهسازى مى كنند.

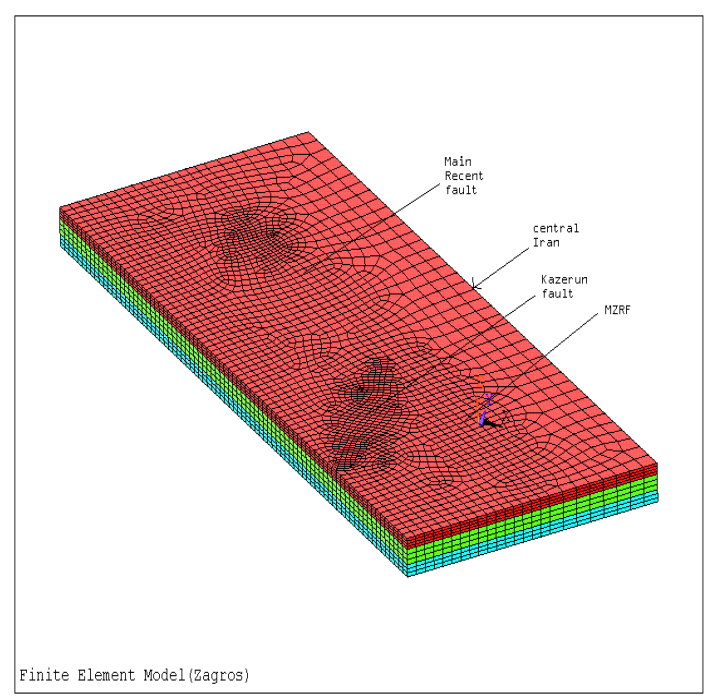

شكل ه. مدل اجزاى محدود شبكهبندى شده. تمامى المان ها خواص ويسكوالاستيك دارند. 


$$
\text { 9- آزمايش مدل }
$$

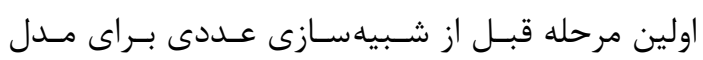

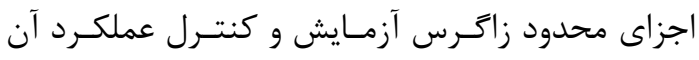

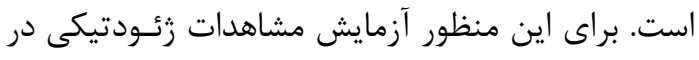

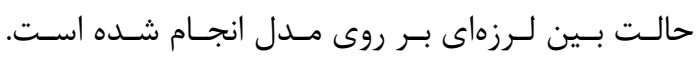

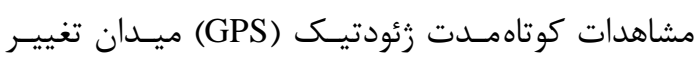

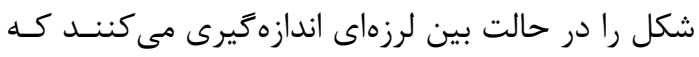

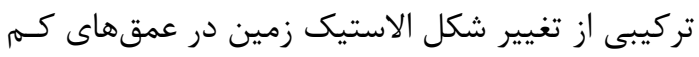

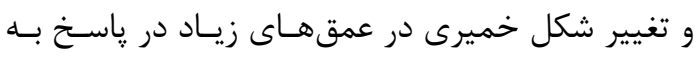

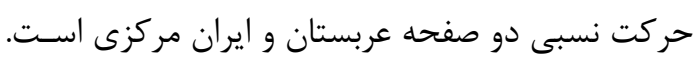

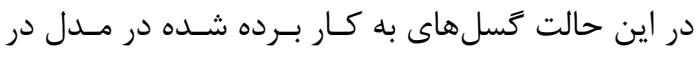

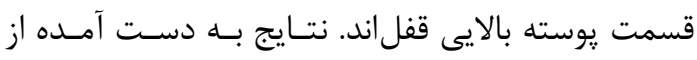
مدل و سرعتهاى حاصل از GPS در منطقه زاخرس بـ بـانـا

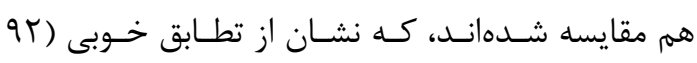

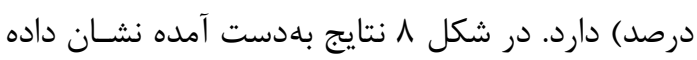

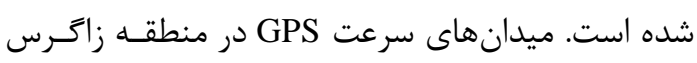
بلهوسيله [ץ] نسبت به ايران مركزى محاسبه شده است.

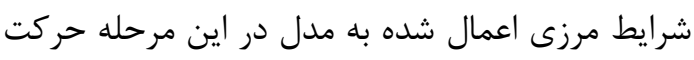

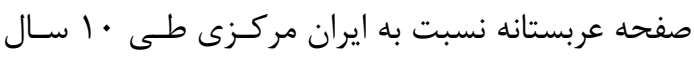

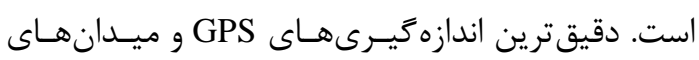
سرعت طى · ا سال اخير محاسبه شده است.

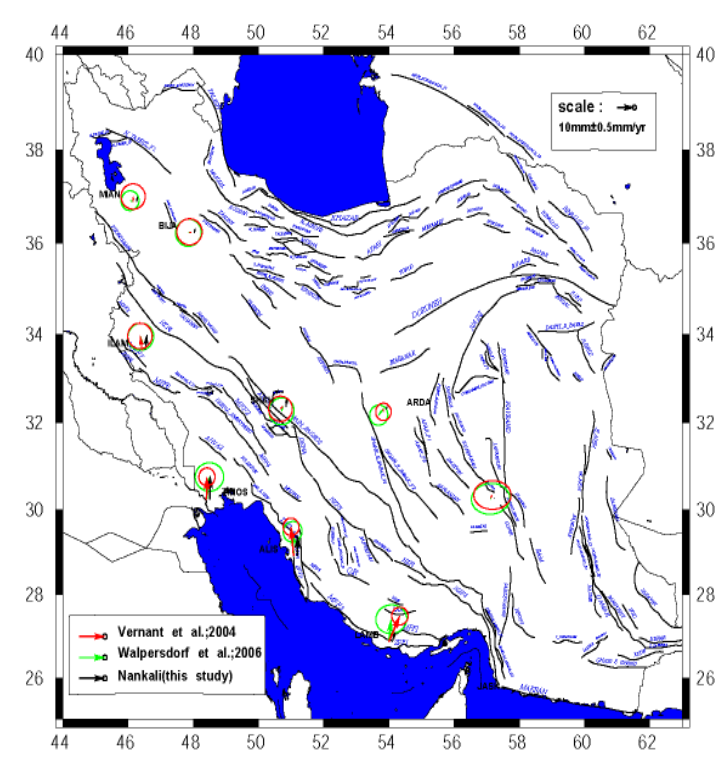

شكل ^. مقايسه سرعتهاى به دست آمده از مدل و نتايج به دست آمده در شبكه ايران سراسرى
دست آمـده از مــدل بـراى بررسـى تغييــر شـكلهـاى خميرى نشان داده شده است.

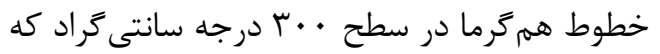
مرز تغيير شكلهاى شكننده است، در عمق بـين 11 | و

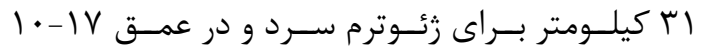

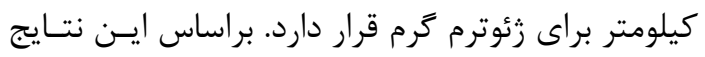

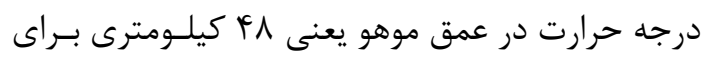

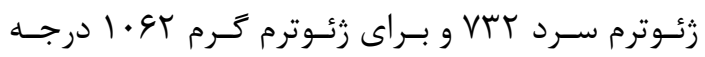

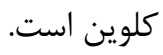

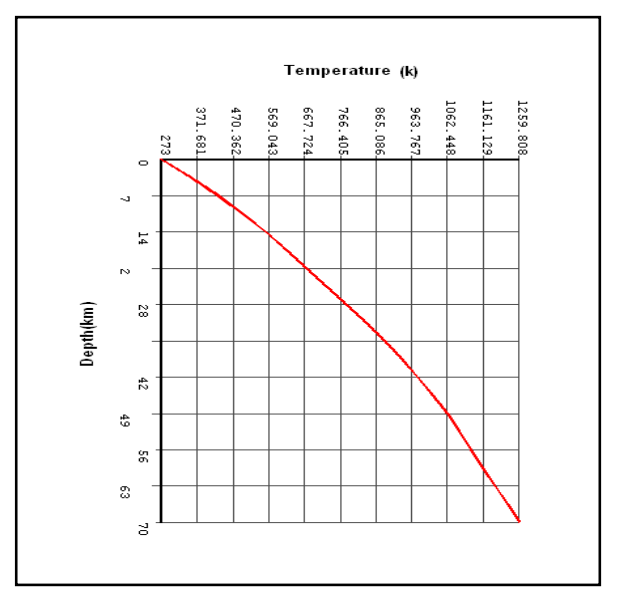

شكل 9. رئوترم محاسبه شده براى رئولوزى سرد كه در مدل

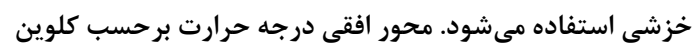

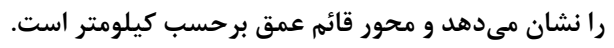

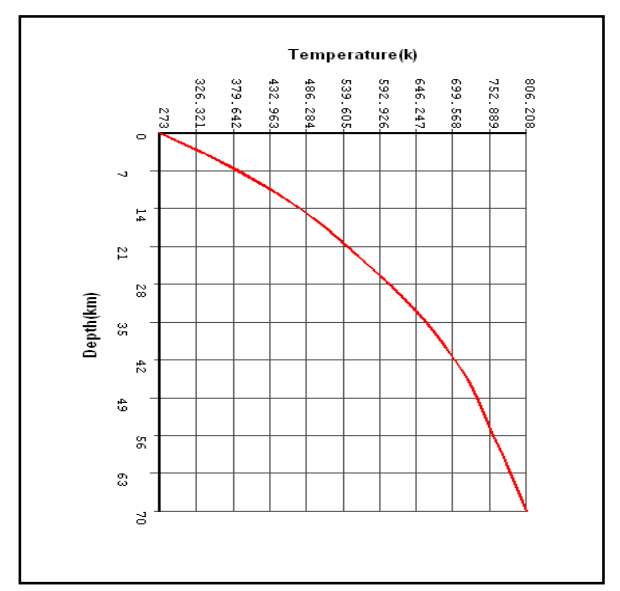

شكل V. زئوترم محاسبه شده براى رئولوزى سرد كه در مدل

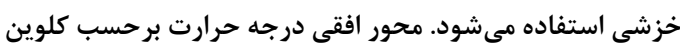
را نشان مىدهد و محور قائم عمق برحسب كيلومتر است. 
كه در آن

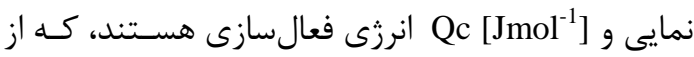
لحاظ تجربى يارامترهاى خواص مواد را تعيين مى كنند

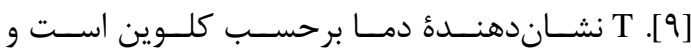

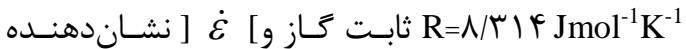
مقدار نرخ استرين و ماسترس است. واضح اسـت كـه براى بررسى رفتار مكانيكى ليتوسفر دو نوع تغييرشـكل را بايستى در نظر گرفت كه عبارت است از تغيير شـكل

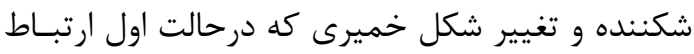
به زلزله دارد ولى تغيير شكل خميـــى قـادر بــه ايجـاد زلزله نيست. مرز بين اين دو تغيير شكل بـه نـام BDT (عبو از تغيير شكل شكننده به خميرى) ناميده مىشود. اين ناحيه در ليتوسفر، زونى است كه زلزلـهـــا در آنجـا اتفاق مىافتند. براى بررسى رفتـار مكـانيكى ليتوسـفر برحسب تفاضل تنشهاى اصلى براى ناحيـه شـكننده و خميرى از رابطه (f) استفاده مىشود.

$\sigma_{1}-\sigma_{3}=\operatorname{A\rho gz}(1-\lambda)$

(f) (f)

$\sigma_{1}-\sigma_{3}=\left(\frac{\dot{\varepsilon}}{\mathrm{A}}\right)^{\frac{1}{\mathrm{n}}} \exp \left(\frac{\mathrm{Q}_{\mathrm{c}}}{\mathrm{nRT}}\right)$

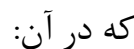

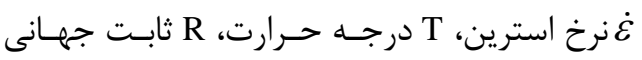

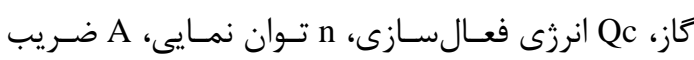

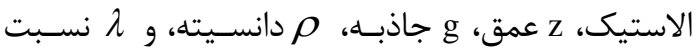
فشار حفرهاى به فشار ليتوستاتيك است. با توجه به روابط مذكور، رفتار مكانيكى ليتوسفر در

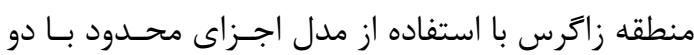

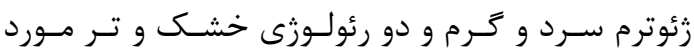
بر ترسى قرار مى تيرد.

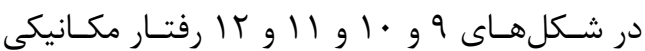
ليتوسفر در منطقه زاگرس براى زئوترم سـرد و گَرم در دو رئولوزى تر و خشك نشان داده شده است.
•ا - محاسبه رفتار مكانيكى ليتوسفر (سنََكُره)

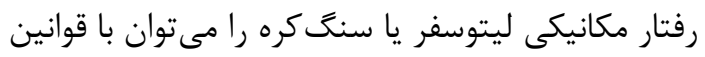

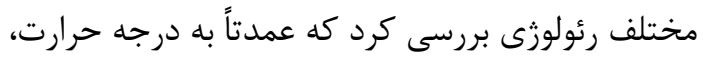
كانى شناسـى، فشـار، كـرنش و ميـزان يـا نــــخ كـرنش بستخى دارد. مهمترين مكانيسمهاى تغييرشـكل، رفتـار الاستيك شكننده و خميرىاند. رفتار الاستيك، كـرنش قابل بازگشت مــواد را در اسـترس تفاضـلى كـم نشـان مى دهد و فقـط جنــد درصــ از تغييـر شـكل را در بـر

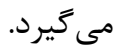

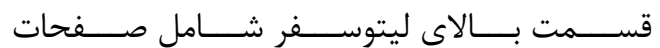

مسـطحشـكننده و گســلهاسـت. بـا اسـتفاده از قـانون آمونتون [V] و لغزش اين صفحات (يـا دو طـرف گسـل نسبت به همم) مى توان بـه تغييـر شـكل هـاى شـكننده

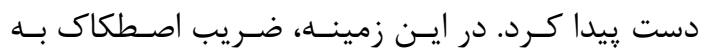

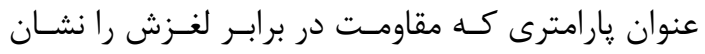
مى دهد، به همراه استرس برشى و استرس نرمال تعريف مى گردد. عمومى ترين مكانيسمى كه براى تشريح تغيير

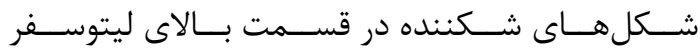
(يوسته) استفاده مى خـردد، شكستـ برشـى اسـت كـهـ

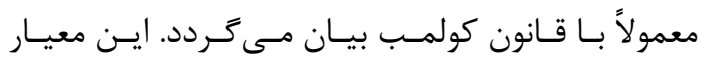
شكست با حذف حسبندكى و با در نظر كرفتن ضـريب

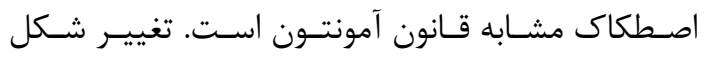

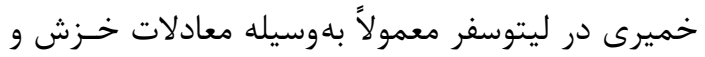
روابط تجربى تشريح مى

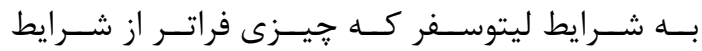

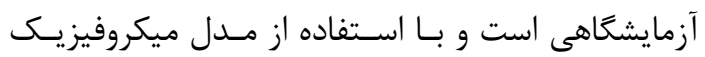
خزش مشخص مىشوند.

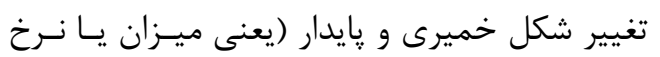
استرين ثابت تحت فشار ثابت) مسى توانـد بـا معادلــاى

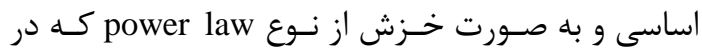

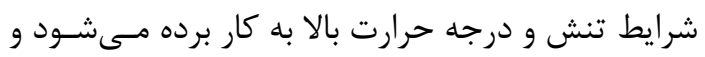
بلهوسيله رابطه (بّ) نشان داده شود.
$\dot{\varepsilon}=\mathrm{A} \exp (-\mathrm{Qc} / \mathrm{RT}) \sigma^{\mathrm{n}}$
رابطه (广) 


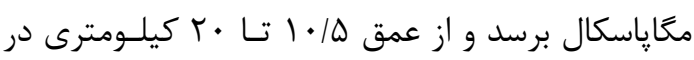

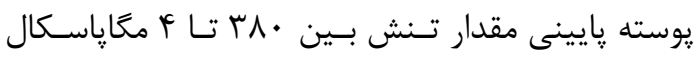

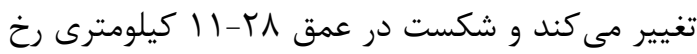

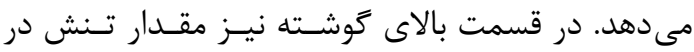

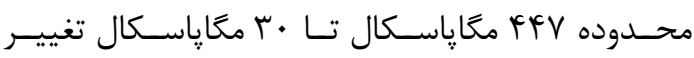
مى كند و هيجَّونه شكستى ديده نمى شود.

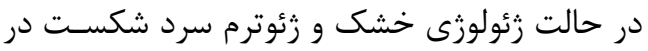

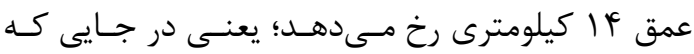

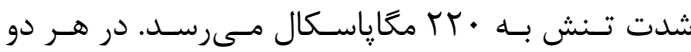

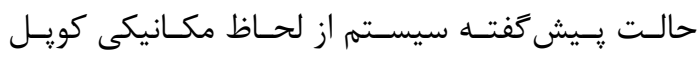

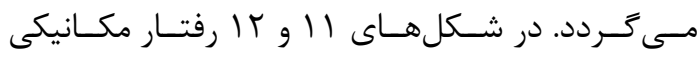
ليتوسفر براى رئولوزى تر و خشك با زئوترم كرم نشـان داده شده است. آنجه كه اهميت دارد، اين است كه مرز

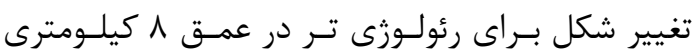

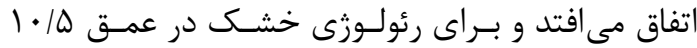
كيلومترى رخ مى دهد، كه خود ناشى از افـزايش درجـهـ حرارت است و همجنين شكست در كوشــه بـالايى در

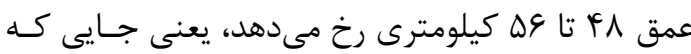

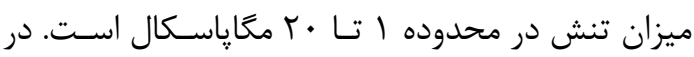
اين حالت سيستم از لحاظ مكانيكى كويل نمىشود.

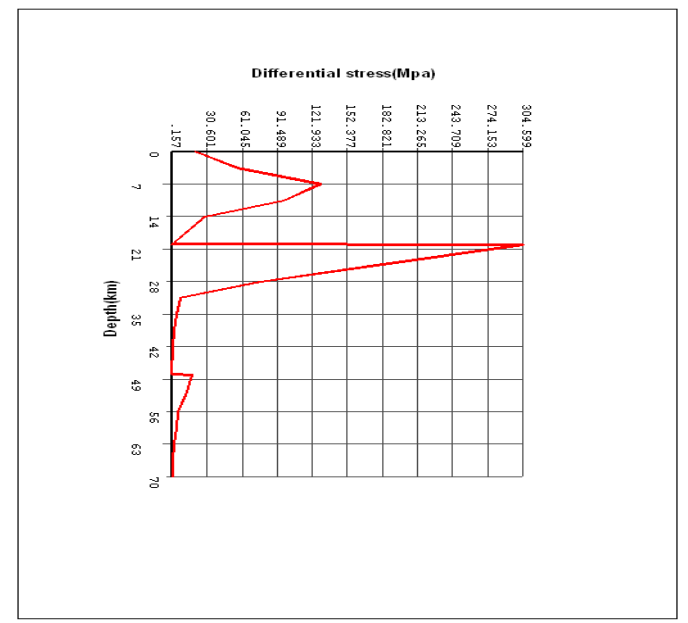

شكل Iا. رفتار مكانيكى ليتوسفر براى رئولوزى تر و

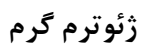

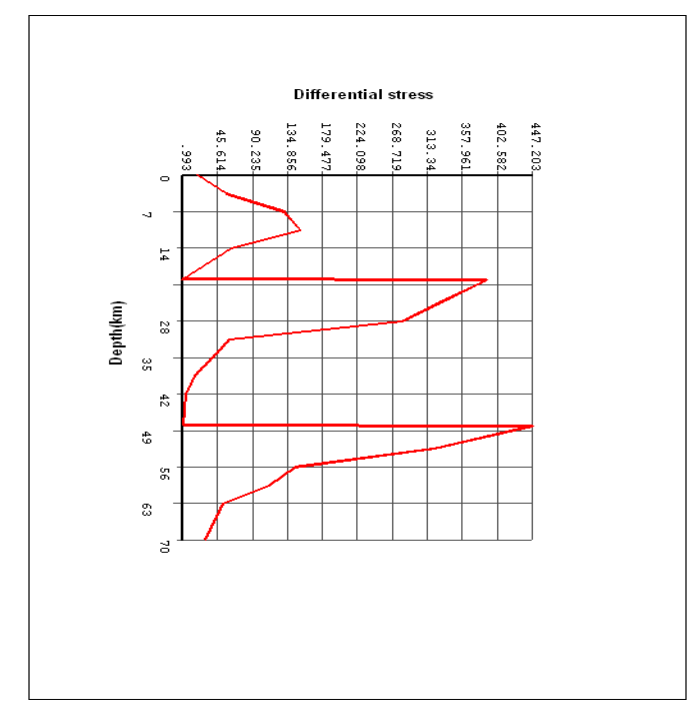

شكل 9.

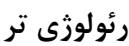

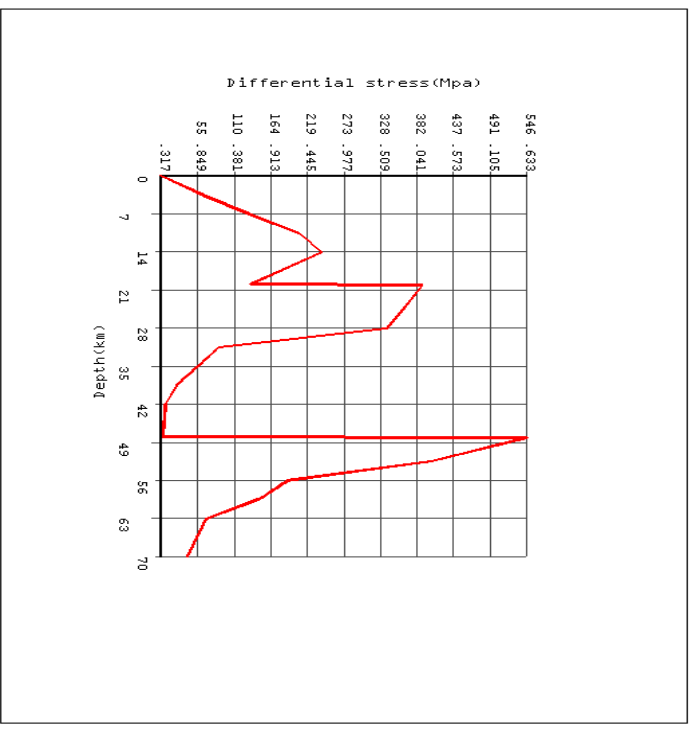

شكل •1. رفتار مكانيكى ليتوسفر براى زئوترم سرد و رئولوزى خشك لينى

در حالت رئولوزى تر و زئسوترم سـرد، در جـايى كـهـ

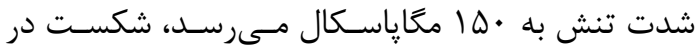

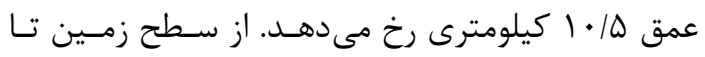

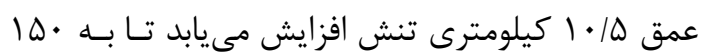


احر رئولوزى خشك را با زئوترم سرد و كَرم در نظـــ

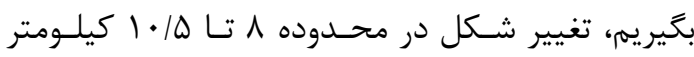

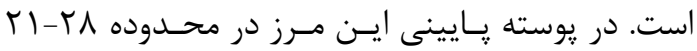
كيلومتر است. براى كرانيت مرز تغيير شكل در محدوده

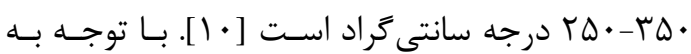
نمودارهاى مربوط به زئوترم مدل اين مرز بـراى زئسوترم

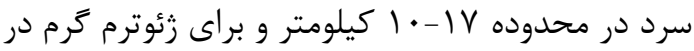

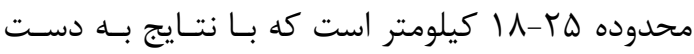

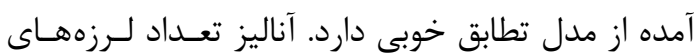

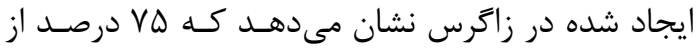

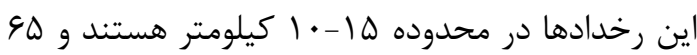

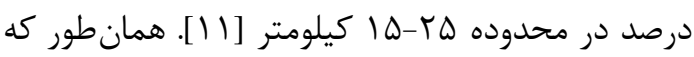

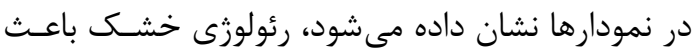

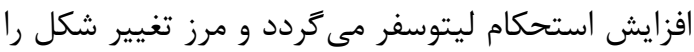

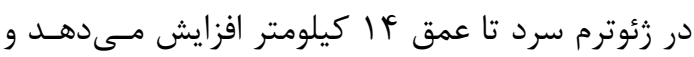

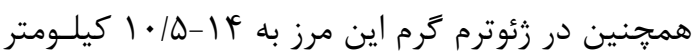

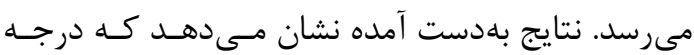

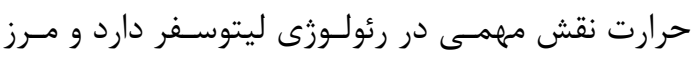

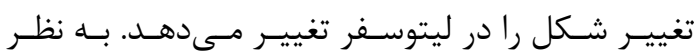

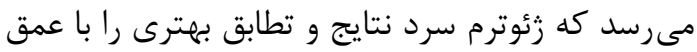

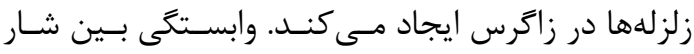

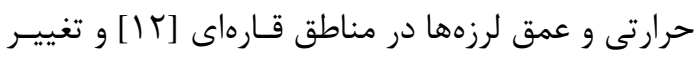

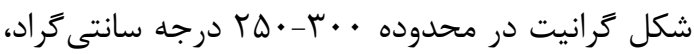

متناسب باعمق •ا تا لم كيلومتر در زاترس است.

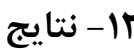

در اين تحقيق يك مدل سهبعدى ويسكوالاستيك براى بررسى و شـبيهسـازى تغييـر شـكلهـاى ليتوسـفر در در

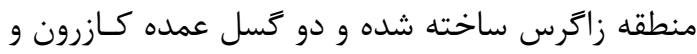

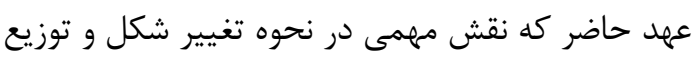

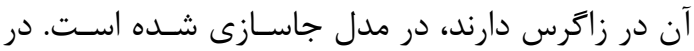

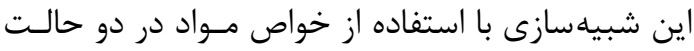

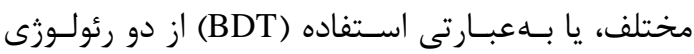
خشك و تـر رفتـار مكـانيكى ليتوسـفر در ايسن منطقـهـ

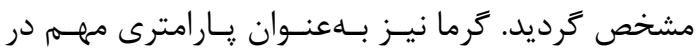

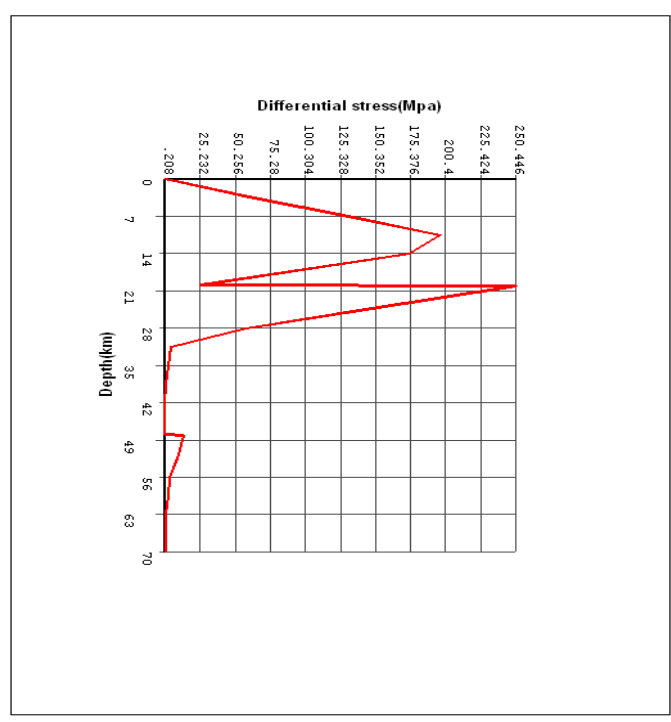

شكل זا. رفتار مكانيكى ليتوسفر براى رئولوزى خشك و

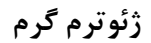

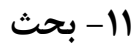
همان طور كه در شكل با إ نشـان داده مسىشـود، اكثـر

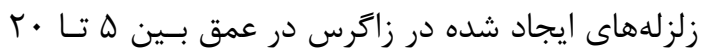

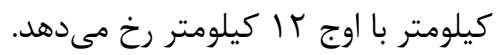
واضح است كه لرزهخيزى در قسمت بـالاى يوسـت

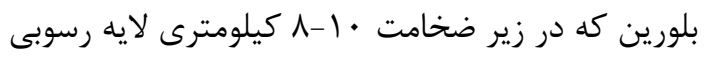

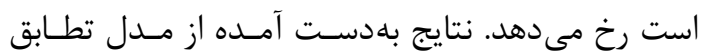
خوبى با اين دادههاى لرزهنگارى دارد.

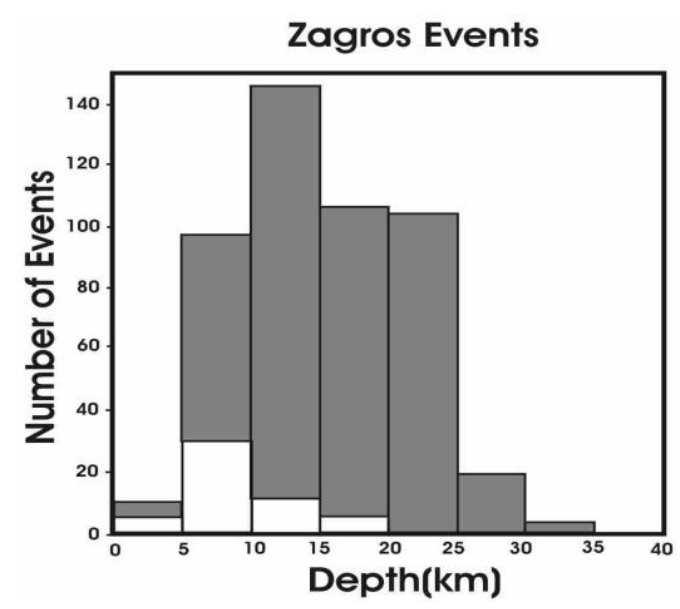

شكل سا. عمق زلزلهها در منطقه زاترس ـ منطقه سفيد با استفاده از روش body wave modeling محاسبه شده است [باس] 
[7] Ranalli, G., 1995. Rheology of the Earth. 2nd edn. London: Allen and Unwin.

[8] Snyder, D.B. and Barazangi, M., 1986. Deep Crustal Structure and Flexure of the Arabian Plate Beneath the Zagros Collisional Mountain Belt as Inferred from Gravity Observations. Tectonics, 5, 361-373.

[9] Kirby, S., 1983. Rheology of the Lithosphere. Reviews of Geophysics and Space Physics, 21, 1458-1487.

[10] Scholz, C.H., 1990. The Mechanics of Earthquakes and Faulting. Cambridge: Cambridge University Press.

[11] Yamini-Fard, F., Hatzfeld, D. and Tatar, M., 2007. Microearthquake Seismicity at the Intersection between the Kazerun Fault and the Main Recent Fault (Zagros, Iran). Geophys, J. Int. 166, 186-196.

[12] Sibson, R.H., 1982. Fault Zone Model, Heat Flow, and the Depth Distribution of Earthquakes in the Continental Crust of the United States. Bull. Seism. Soc. Am., 72, 151-163.

[13] Engdahl, E.R., Jackson, J.A., Myers, S.C., Bergman, E.A. and Priestley, K., 2006. Relocation and Assessment of Seismicity in the Iran Region. Geophys, J. Int. 167, 761-778.

$$
\begin{aligned}
& \text { تغيير شكل ليتوسفر در اين مدلسازى اسـتفاده شـد و ود }
\end{aligned}
$$

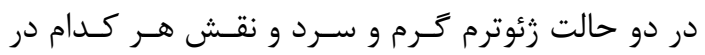

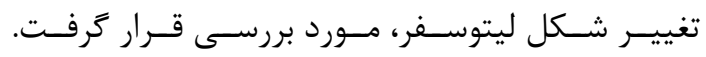

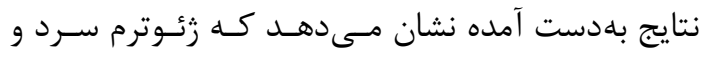

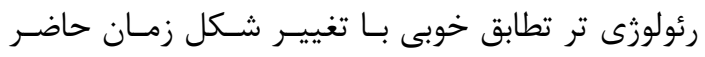

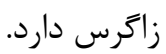

$$
\begin{aligned}
& \text { نيروى افقى مورد نياز براى ايجاد تغيير شـكلهـاى داى داد } \\
& \text { Inelastic } \\
& \text { دو ريولوزى كرم و سرد مورد بررسى قـرار كرفـت كـهـ دئه } \\
& \text { مقادير آن در ريولوزى خشك و تر با زئوترم سـرد بـ بـين }
\end{aligned}
$$

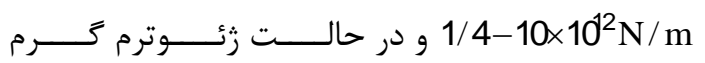

$$
\begin{aligned}
& \text { 0/1-0/4×10 } 10^{2} \mathrm{~N} / \mathrm{m}
\end{aligned}
$$

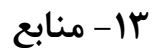

[1] McKenzie, D.P., 1972. Active Tectonics of the Mediterranean Region. Geophys. J.R, Astron. Soc., 30, 109-185.

[2] DeMets, C., Gordon, R.G., Argus, D.F. and Stein, S., 1990. Current Plate Motions. Geophys, J. Int, 101, 425-478.

[3] Vernant, P. et al., 2004. Present-day Crustal Deformation and Plate Kinematics in the Middle East Constrained by GPS Measurements in Iran and Northern Oman. Geophys, J. Int., 157, 381-398.

[4] Vernant, P. and Chéry, J., 2006. Low Fault Friction in Iran Implies Localized Deformation for the Arabia-Eurasia Collision Zone. Earth and Planetary Science Letters, 246, 197-206.

[5] Tlebian, M. and Jackson, J., 2004. A Reappraisal of Earthquake Focal Mechanisms and Active Shortening in the Zagros Mountains of Iran. Geophys, J.Int., 156, 506-526.

[6] Hatzfeld, D., Tatar, M., Priestley, K. and Ghafory-Ashtyany, M., 2003. Seismological Constraints on the Crustal Structure Beneath the Zagros Mountain Belt (Iran). Geophys, J. Int., 155, 403-410. 


\title{
3D Finite Element Modelling of Lithospheric Strength in Zagros Mountains
}

\author{
Nankali H.R.*1, Vosooghi B. ${ }^{2}$, Sobouti F. ${ }^{3}$, Hessami K. ${ }^{4}$ \\ 1- Ph.D. of Geodesy, National Cartographic Center of Iran \\ 2- Associate Prof. in Faculty of Geodesy and Geomatics Engineering, K. N. Toosi University of Technology \\ 3- Assisstant Prof. in Dep. of Physics, Institute for Advanced Studies in Basic Sciences, Zanjan \\ 4- Assisstant Prof. in International Institute of Earthquake of Engineering and Seismology
}

\begin{abstract}
A three-dimensional lithosphere model with horizontal dimensions of $1500 \times 600 \mathrm{~km}$. and a depth extent of $70 \mathrm{~km}$. is constructed from available geophysical data to find out strength (as the maximum deviatoric stress the lithosphere supports at a given depth) in Arabia-Eurasia plate boundary zone. The constructed model is first used in the calculation of thermal initial condition and then strength envelopes were calculated using the obtained geotherm and rheological flow laws. Numerical models are run for initial temperature distributions representing cold and hot lithospheres with two different rheologies (wet and dry).The obtained mechanical structures were analyzed and compared with other geophysical data; e.g., seismicity-depth and isotherm-depth distributions. Model results for wet and dry rheologies indicate that the depth of the brittle-ductile transition is about $8 \mathrm{~km}$., and $11 \mathrm{~km}$. for hot geotherm and $10.5 \mathrm{~km}$. to14 $\mathrm{km}$. and 21-28 for the cold one. The results are in good agreement with focal depth in the Zagros that most earthquakes occur in 8 to $15 \mathrm{~km}$. depth (Tatar et al., 2004 and Jackson et al., 2008) that the longterm strength of the continental lithosphere resided only in its upper part, which was contained wholly within the crust.
\end{abstract}

Keywords: Rheology, Finite-element methods, Brittle, Geotherm, Iran.

Correspondence Address: National Cartographic Center of Iran, Geodesy and Geodynamics Department, Azadi square, Tehran, Iran. Tel: 66071092 Email: nankali@ncc.org.ir 